\title{
Physical Properties of Rice Husk-Pine Wood Particleboard
}

\author{
Z. Z. Low ${ }^{1}$, T. C. Lee', M. A. Selimin'1, N. A. $\operatorname{Pagan}^{2}$, J. A. Halip ${ }^{1 *}$ \\ ${ }^{1}$ Department of Production and Operations, Faculty of Technology Management and Business, \\ Universiti Tun Hussein Onn Malaysia, Batu Pahat, 86400, MALAYSIA \\ ${ }^{2}$ Evergreen Fibreboard Berhad, PLO 22, \\ Parit Raja Industrial Estate, Batu Pahat, Johor, 86400, MALAYSIA \\ *Corresponding Author
}

DOI: https://doi.org/10.30880/jsmpm.2021.01.01.002

Received 03 October 2021; Accepted 22 November 2021; Available online 08 December 2021

\begin{abstract}
Rice husk is one types of sustainable and economical agricultural wastes that could produce particleboard as the substitute for solid wood. The problems that encourage this research are due to the increasing of deforestation and the increment demand for solid wood in various industries. Malaysia produces a significant amount of agricultural biomass waste every year. It is noteworthy to mention that agricultural wastes can be fully used in an environmentally friendly way. This study aims to evaluate the properties of particleboard made from rice husk at different fibre loading and mixture. Different formulated composition of rice husk and pine wood shaving was prepared for the production of particleboard by hot pressing at temperature $160{ }^{\circ} \mathrm{C}$ for 6 min using UreaFormaldehyde (UF) resin with additional of ammonium chloride $\left(\mathrm{NH}_{4} \mathrm{Cl}\right)$ as a hardener. The results showed the density values and moisture content of particleboards ranging from 0.547 to $0.660 \mathrm{~g} / \mathrm{cm}^{3}$ and 8.072 to $8.929 \%$, respectively. The thickness swelling and water absorption were increased as the increment of soaking time. Besides, the colour of the rice husk-pine particleboards has no significant difference and changes except for particleboard made from $100 \%$ rice husk. While the more proportion of pine wood shaving has the better compaction of particleboards, and the addition of grinded rice husk also make the particleboards have fewer voids. This study is expected to reduce deforestation activities and to maximize the usage of agricultural wastes.
\end{abstract}

Keywords: Particleboard, rich husk, deforestation, production

\section{Introduction}

Rice husk (or rice hull) is the outer covering on rice grain or seed and is a by-product of rice production during the milling process. It is including hard materials such as lignin and silica which can protect the seed during the growing season. According to Singh, current rice production in the world is estimated to be 700 million tons, in roughly $20 \%$ of the paddy production is paddy residue such as rice husk and rice straw [1]. According to the statistic compiled by the Malaysian Ministry of Agricultural, through the milling and harvesting processes had produced approximately 0.48 million tons of rice husk in Malaysia [2].

Rice husk is a rich waste material in all rice-producing countries. It contains about $30 \%$ to $50 \%$ of organic carbon. Rice husk is considered to be a waste that usually throws or burned in open places, and it may cause environmental pollution and damage to the land [3]. Only a few amounts of rice husk have been used to produce brick, for generating heat for rice dryers, and for gasifiers and steam engines used to power rice mills. Many construction industries had used rice husk as raw material because of its low bulk density $\left(90-150 \mathrm{~kg} / \mathrm{m}^{3}\right)$, abrasive in nature, high availability, toughness, unique composition, and resistance to weathering [4].

As the demand to utilize wood-based products were increase because solid wood has the basic features which are more competitively than other materials [5]. In order to ensure the raw material can be supplied continuously, had led to 
extensive logging. Deforestation was caused an enormous impact on biodiversity and loss of habitats, emissions of greenhouse gases, ecological imbalance, flooding, migration of wildlife, and soil erosion [6]. Agricultural waste accounts for $61 \%$ of total waste in Malaysia [7]. These agricultural wastes could produce various useful products such as particleboard that can be used for several applications which not only provides sustainable and cheap resource materials but also reduces environmental pollution [8]. Due to the low supply of high-quality wood, wood wastes and inferior wood had been widely used to produce particleboard as the substituted products [9]. Particleboard is usually used in furniture and floor or wall panels due to its denser, cheaper, and more uniform characteristics compared to solid wood and plywood. Rice husk is one of the agricultural wastes that can be promisingly used to manufacture particleboards. According to United States Department of Agriculture, the global production of milled rice was 488 million tons in 2017. Pinewood shaving has been chosen to add to the production of three-layer particleboards as the surface layers due to it has a higher aspect ratio and good durability compared to rice husk [10].

Particleboard is a wood composite panel made from lignocellulosic materials with a binder or resin under heat and pressure to improve the properties. Generally, particleboards can be classified into seven different classes based on their properties accordance with the British Standard EN 312. The manufacturing process of particleboard is simple and do not require additional process. To manufacture particleboard with equal swelling, smooth surfaces, and good strength, manufacturers preferably use a homogeneous raw material [11]. There are many factors affecting the characteristics of the particleboards and the most prominent such as compressibility, species of wood, hardness, fibre structure, density, type and size of particles, and technique of particle drying. Other factors include particle screening and separation, particle size distribution, type and number of binding agents, method of mat formation, moistening of particles prior to pressing, conditioning, curing conditions, thickness of board [12]. This research aims to evaluate the properties of rice husk-pine wood particleboard at different fibre loading and mixture according to Japanese Industrial Standard A 5908:2003.

\section{Methodology}

\subsection{Preparation of Materials}

Three types of particles were prepared to produce the particleboard which were Rice Husk (RH), Grinded Rice Husk (GRH), and Pinewood Shaving (W). All the particles prior to the production of the boards were separately dried using a laboratory oven (Model Memmert UFE 600 Sterilizer) with temperature $80{ }^{\circ} \mathrm{C}$ for 4 hours to reach a moisture content of approximately $5 \%$ and keep in the zipped plastic bag to avoid exposure to moisture in the air. The Urea-Formaldehyde (UF) resin was used as a binder. As a hardener, $1-2 \%$ ammonium chloride $\left(\mathrm{NH}_{4} \mathrm{Cl}\right)$ based on the UF resin solids content was added to the UF resin solution.

\subsection{Mixing of Particles}

A total of eight types of the particleboards were produced with different types and ratios of particles as shown in Table 1 . The $12 \%$ of UF resin was added ammonium chloride and sprayed on the particles separately to obtain a homogenized mixture according ratio as shown in Table 2.

Table 1 - Composition of particleboard

\begin{tabular}{lcccc}
\hline Type & Fibre loading & RH $(\mathbf{g})$ & GRH $(\mathbf{g})$ & W $(\mathbf{g})$ \\
\hline UG Mixture & $100 \mathrm{RH}: 0 \mathrm{~W}$ & 755.1 & 0 & 0 \\
& $60 \mathrm{RH}: 40 \mathrm{~W}$ & 453.1 & 0 & 287.7 \\
& $40 \mathrm{RH}:$ : $0 \mathrm{~W}$ & 302.1 & 0 & 431.5 \\
G Mixture & $20 \mathrm{RH}: 80 \mathrm{~W}$ & 151.0 & 0 & 575.4 \\
& $100 \mathrm{RH}: 0 \mathrm{~W}$ & 604.1 & 151.0 & 0 \\
& $60 \mathrm{RH}: 40 \mathrm{~W}$ & 362.5 & 90.6 & 287.7 \\
& $40 \mathrm{RH}: 60 \mathrm{~W}$ & 241.7 & 60.4 & 431.5 \\
& $20 \mathrm{RH}: 80 \mathrm{~W}$ & 120.8 & 30.2 & 575.4 \\
\hline
\end{tabular}

Table 2 - Ratio of adhesive

\begin{tabular}{lcccc}
\hline Particles (\%) & 100 RH : 0 W & 60 RH : 40 W & 40 RH : 60 W & 20 RH : 80 W \\
\hline Adhesive (g) & $144.3: 0$ & $86.5: 57.7$ & $57.7: 86.5$ & $28.9: 115.4$ \\
\hline$* *$ 12 UF resin: $142.6 \mathrm{~g}+1$ hardener: $1.66 \mathrm{~g}$ & &
\end{tabular}




\subsection{Forming and Pressing}

The wooden mould was placed on the steel plate, the particles were distributed manually into the mould by layers. The lid of the mould was then pushed into the mould and manually pre-pressed. After that, the mould and lid have been taken out and the mats were undergoing the hot-pressing process by using the hot press machine (Model Wabash G302H15-ASTM). Another steel plate was placed on the mat and two stoppers were placed at both sides of the mat and then were pressed into $10 \mathrm{~mm}$ thick boards using pressure 15 tons force and press at temperature $160{ }^{\circ} \mathrm{C}$ for 6 min. To prevent the particles from contact directly with the steel plates during the hot press process, the release agent (WD-40) has been used.

\subsection{Characterisation}

\section{(a) Density Test}

The density was calculated using the weight of the specimen $\left(\mathrm{m}_{1}\right)$ divided by the volume of the specimen $(\mathrm{V})$. All boards are targeted to produce with a density of 400 to $900 \mathrm{~kg} / \mathrm{m}^{3}$ were able to meet the minimum strength requirement of Japanese Industrial Standard (JIS) A 5908:2003. The higher density values, the higher property of the particleboards [13].

\section{(b) Moisture Content (MC)}

To determine the moisture content of particleboards, the specimens were weighed $\left(\mathrm{m}_{1}\right)$ after conditioning a few days in environmental temperature and also determined the oven-dried weight $\left(\mathrm{m}_{0}\right)$ after drying the specimens at temperature $105{ }^{\circ} \mathrm{C}$ for 4 hours using a laboratory oven. Moisture content was calculated as follows:

$$
M C=\frac{m_{1}-m_{0}}{m_{0}} \times 100
$$

\section{(c) Dimensional Stability Test}

The weight percentage gain and thickness changes of specimens were measured after immersion in water as stated in the previous study [14]. The specimens' thickness and weight were evaluated before $\left(t_{1}\right)$ and after $\left(t_{2}\right)$ the submersion into the water for 2 hours, 24 hours, 48 hours, 72 hours, and 96 hours at room temperature. The values of thickness swelling (TS) and water absorption (WA) were calculated as following:

$$
\begin{aligned}
& T S=\frac{t_{2}-t_{1}}{t_{1}} \times 100 \\
& W A=\frac{w_{2}-w_{1}}{w_{1}} \times 100
\end{aligned}
$$

\section{(d) Colour Analysis}

For the colour analysis, the relationship between the composition and colour changes of the panel board had been observed. The result of each board may no significant difference in terms of colour due to the surface layer were made by pine wood shavings, other than the single-layer particleboard with $100 \%$ of rice husk.

\section{(e) Void Content}

In this study, the void content of particleboards has been observed. The result of each specimen may differ in terms of void content due to the different ratios of the fibre loading. A great number of voids per unit area are sufficient to cause failure under stress and eventually give low strength properties [15].

\section{(f) Statistical Analysis}

The data obtained were statistically analyzed using Statistical Analysis System (SAS) software. Analysis of variance (ANOVA) was used to determine whether there were differences in the particleboard with the various ratios on the properties was carried out [14]. Mean separation was carried out using the least significant difference (LSD) method.

\section{(g) Particleboards Specification}

The specification of particleboards was measured in compliance with the JIS A 5908:2003. 


\section{Results and Discussion}

\subsection{Density Test}

The density of the particleboards was determined according to the requirement of JIS A 5908:2003, which was 400 to $900 \mathrm{~kg} / \mathrm{m}^{3}$. The density values were calculated by the average values of six specimens for each type of particleboard. All the particleboards had reached the minimum density requirement from approximately 0.547 to $0.660 \mathrm{~g} / \mathrm{cm}^{3}$ as tabulated in Table 3.

Table 3 - Density of particleboard

\begin{tabular}{lcc}
\hline Ratio & Mixture & Density $\left(\mathbf{g} / \mathbf{c m}^{\mathbf{3}}\right)$ \\
\hline $100 \mathrm{RH}: 0 \mathrm{~W}$ & $\mathrm{G}$ & $\mathbf{0 . 5 6 1}$ \\
& $\mathrm{UG}$ & 0.556 \\
$60 \mathrm{RH}: 40 \mathrm{~W}$ & $\mathrm{G}$ & $\mathbf{0 . 5 9 4}$ \\
& $\mathrm{UG}$ & 0.547 \\
$40 \mathrm{RH}: 60 \mathrm{~W}$ & $\mathrm{G}$ & 0.595 \\
& $\mathrm{UG}$ & $\mathbf{0 . 6 6 0}$ \\
$20 \mathrm{RH}: 80 \mathrm{~W}$ & $\mathrm{G}$ & $\mathbf{0 . 5 8 0}$ \\
& UG & 0.566 \\
\hline
\end{tabular}

For constant pressure and the same binder content, the density values were mainly affected by the mixture of grinded (G) rice husk. However, the different composition has no significant influence on the density values of particleboards. The highest density value was obtained from the boards with a ratio of $40 \mathrm{RH}$ : $60 \mathrm{~W}$, while the $60 \mathrm{RH}$ : $40 \mathrm{~W}$ boards with ungrounded (UG) rice husk has obtained the lowest density value. Overall, the $100 \mathrm{RH}: 0 \mathrm{~W}, 60 \mathrm{RH}: 40 \mathrm{~W}$, and $20 \mathrm{RH}$ : $80 \mathrm{~W}$ boards with consist of grinded rice husk have better (higher) density values compared to the boards without the mixture of grinded rice husk, while the boards with ratio $40 \mathrm{RH}$ : $60 \mathrm{~W}$ vice versa. The higher density values may improve properties and increases the bending strength of particleboards. Therefore, the $40 \mathrm{RH}: 60 \mathrm{~W}$ particleboards had better dimensional stability properties (higher density values) in comparison to $60 \mathrm{RH}$ : $40 \mathrm{~W}$ boards.

From observation, density of panel with a presence of pine is slightly higher compared to those made from $100 \%$ rice husk. This is due to higher density of pinewood compared to rice husk [16]. As compared to grinded (G) rice husk, panel with ungrinded rice husk apparently have course particle. According to previous study, the particleboard with course particles slightly has higher density [17]. Higher density normally will lead to high strength of board panel.

\subsection{Moisture Content (MC)}

The moisture content (MC) of particleboards was measured before and after oven-dried specimens using a laboratory oven with the temperature of $105^{\circ} \mathrm{C}$ for 4 hours. The MC values of particleboards in this study were fulfilled JIS A 5908. This standard required an MC value between 5 and $13 \%$. As can be seen that the MC values presented in Table 4, the MC values of particleboards obtained in this study were in the range from 8.072 to $8.929 \%$, which has met the requirement of JIS A 5908.

Table 4 - Moisture content of particleboard

\begin{tabular}{lcc}
\hline Ratio & Mixture & Moisture Content (\%) \\
\hline $100 \mathrm{RH}: 0 \mathrm{~W}$ & $\mathrm{G}$ & 8.929 \\
& $\mathrm{UG}$ & 8.072 \\
$60 \mathrm{RH}: 40 \mathrm{~W}$ & $\mathrm{G}$ & 8.325 \\
& $\mathrm{UG}$ & 8.440 \\
$40 \mathrm{RH}: 60 \mathrm{~W}$ & $\mathrm{G}$ & 8.434 \\
& $\mathrm{UG}$ & 8.814 \\
$20 \mathrm{RH}: 80 \mathrm{~W}$ & $\mathrm{G}$ & 8.798 \\
& $\mathrm{UG}$ & 8.433 \\
\hline
\end{tabular}

The highest MC value was obtained from a board prepared from $100 \mathrm{RH}: 0 \mathrm{~W}$ with the mixture of grinded rice husk, whereas the minimum value was obtained from that prepared from $100 \mathrm{RH}$ : $0 \mathrm{~W}$ without the mixture of grinded rice husk. Overall, there was insignificant influence of different fibre loading compositions. However, from the perspective of mixture, in $100 \mathrm{RH}$ : $0 \mathrm{~W}, 60 \mathrm{RH}$ : $40 \mathrm{~W}$, and $20 \mathrm{RH}$ : $80 \mathrm{~W}$ boards without consist of grinded rice husk have lower MC values compared to the boards with mixture of grinded rice husk, while the boards with ratio $40 \mathrm{RH}$ : $60 \mathrm{~W}$ vice versa. 
Lower moisture content will irregularly bend the board, while a higher moisture content will affect the strength of particleboards [18]. In all phases of the production process, particleboard's moisture levels are critical. The moisture content defines the board's durability and strength. Moreover, the board's surface appearance and performance are affected by the distribution of moisture.

Chalapud et al. [13] reported that the rice husk particleboards with no impregnated tung oil had obtained a higher moisture content of $7.65 \pm 0.01 \%$ compared to the impregnated with tung oil particleboards $5.59 \pm 0.09 \%$. It is due to the tung oil filling ability and hydrophobic character caused the particleboards had lower moisture content. While Ciannamea et al. concluded that the boards with $11 \%$ of binder content and press at pressure 0.83 MPa have the highest $\mathrm{MC}$ of $5.8 \pm 0.3 \%$ [19]. While the lowest MC was obtained from the boards with $0.28 \mathrm{MPa}$ pressure and $8 \%$ binder content. Hence, the moisture content of particleboards was affected by the content of the resin and the pressure of pressing.

\subsection{Dimensional Stability}

The thickness swelling tested the particleboard's reaction to the frequent wetting or exposure to intense moist conditions for certain periods. Whereas the testing of water absorption is to evaluate the water affinity property of the particles. In this testing, six specimens from each type of particleboard were used to immerse in water for up to four days. The thickness and weight of all particleboards were measured before submersion in water and after 2 hours, 24 hours, 48 hours, 72 hours, and 96 hours of submersion in water. The calculations were carried out to obtain the percentages of Thickness Swelling (TS) and Water Absorption (WA) after the thickness and weight of the humidified specimens was measured.

The thickness swelling namely TS2, TS24, TS48, TS72, and TS96 were highly influenced by the interaction between ratio and mixture of particles as presented in Table 5. However, there is no interaction effect was observed for all water absorption properties. Among both parameters, the thickness swelling apparently more affected by the ratio than the mixture.

Table 5 - ANOVA analysis for thickness swelling and water absorption

\begin{tabular}{lcccccccccccc}
\hline \multirow{2}{*}{ Source } & \multirow{2}{*}{ DF } & \multicolumn{10}{c}{ p-value } & \multicolumn{10}{c}{} \\
\cline { 2 - 13 } & & TS2 & TS24 & TS48 & TS72 & TS96 & WA2 & WA24 & WA48 & WA72 & WA96 \\
\hline Ratio & 3 & 0.0017 & 0.0001 & 0.0001 & 0.0001 & 0.0001 & 0.6171 & 0.9196 & 0.9813 & 0.7869 & 0.3589 \\
& & $* * *$ & $* * *$ & $* * *$ & $* * *$ & $* * *$ & $\mathrm{~ns}$ & $\mathrm{~ns}$ & $\mathrm{~ns}$ & $\mathrm{~ns}$ & $\mathrm{~ns}$ \\
Mixture & 1 & 0.6488 & 0.1400 & 0.0618 & 0.0438 & 0.0297 & 0.1402 & 0.1480 & 0.6484 & 0.7069 & 0.5411 \\
& & $\mathrm{~ns}$ & $\mathrm{~ns}$ & $*$ & $* *$ & $* *$ & $\mathrm{~ns}$ & $\mathrm{~ns}$ & $\mathrm{~ns}$ & $\mathrm{~ns}$ & $\mathrm{~ns}$ \\
Ratio*Mixture & 3 & 0.0065 & 0.0012 & 0.0009 & 0.0010 & 0.0009 & 0.2379 & 0.4718 & 0.7392 & 0.5248 & 0.2901 \\
& & $* * *$ & $* * *$ & $* * *$ & $* * *$ & $* * *$ & $\mathrm{~ns}$ & $\mathrm{~ns}$ & $\mathrm{~ns}$ & $\mathrm{~ns}$ & $\mathrm{~ns}$ \\
\hline
\end{tabular}

Note: Experimental coefficient of variation,

ns : Not significant

* : : Significantly different at $\mathrm{p} \leq 0.1$

$* *$ : Significantly different at $\mathrm{p} \leq 0.05$

$* * *:$ Significantly different at $\mathrm{p} \leq 0.01$

Fig. 1 shows the thickness swelling (TS) values of particleboards in percentage after 2 hours, 24 hours, 48 hours, 72 hours, and 96 hours of submersion in water. The TS values were the average values of six specimens from the same ratio and mixture particleboards. Overall, the TS values of all types of particleboards with different ratio and mixture were increased as the increment of time. The specimens with the ratio of $20 \mathrm{RH}: 80 \mathrm{~W}$ have the lowest TS values which indicated high dimensional stability of the board after up to 96 hours of submerged time. While the highest TS values were the boards with the ratio of $60 \mathrm{RH}: 40 \mathrm{~W}$. The RH particleboard without wood shaving has low dimensional stability, which indicates that the bonding strength between rice husk particleboard is weak, whereas a high amount of wood shaving gives better stability (low TS values). Besides, $100 \% \mathrm{RH}$ board with the mixture of grinded rice husk has comparable TS values with $20 \mathrm{RH}: 80 \mathrm{~W}$. From the perspective of mixture, there are less significant effect of mixture in the same ratio except in $100 \mathrm{RH}$ : $0 \mathrm{~W}$ board. In $100 \mathrm{RH}: 0 \mathrm{~W}$ and $20 \mathrm{RH}: 80 \mathrm{~W}$, the board consists of grinded particles that have better (lower) TS values compared to those with ungrinded rice husk, while $60 \mathrm{RH}: 40 \mathrm{~W}$ and $40 \mathrm{RH}: 60 \mathrm{~W}$ boards, vice versa. In general, there are various chemical and anatomical properties in different lignocellulosic materials that may influence their water absorption and swelling. The level of stress and its potential impact on TS depend on the adhesive's ability to tolerate alternating swelling between adjacent particles [20].

Melo et al. [21] had evinced that particleboard produced with rice straw showed high water absorption and thickness swelling, which significantly reduced when the particleboards were mixed with wood in the same proportion. The percentage values were the average values of six specimens from the same ratio and mixture particleboards. Meanwhile, 
Fig. 2 shows no significant effect on the water absorption (WA) properties of the particleboards with different ratio and mixture, where the WA taken at the same immersion time has a nearly identical quantity.

The WA values were also kept increased with the growth of time. The board with a ratio of 60 RH: $40 \mathrm{~W}$ has the lowest WA values which indicated high dimensional stability of board after submerged in water after 2 and 24 hours, however after up to 96 hours submerged time, the $20 \mathrm{RH}: 80 \mathrm{~W}$ boards have the lowest WA values. The highest WA values were observed from the boards with a ratio of $40 \mathrm{RH}$ : $60 \mathrm{~W}$ after 2, 24, and 48 hours, while after 72 and 96 hours the highest WA values were obtained from $60 \mathrm{RH}$ : $40 \mathrm{~W}$ board. The board with a higher amount of wood shaving having lower WA values whereby provided better stability of particleboards. Moreover, from the perspective of mixture, there was less significant effect of the mixture in the same ratio. In $60 \mathrm{RH}: 40 \mathrm{~W}$ and $40 \mathrm{RH}: 60 \mathrm{~W}$, the board consists of grinded particles have better (lower) WA values compared to those with ungrinded rice husk. Whereas the board with ratio $100 \mathrm{RH}$ : $0 \mathrm{~W}$ and $20 \mathrm{RH}: 80 \mathrm{~W}$, vice versa. WA was usually caused by the water spread through the amorphous region of cellulose in raw materials when water penetrates into the board. The result of higher WA values obtained from the board consists of a larger amount of rice husk because the chemical composition of rice husk had interfered in the physical properties and bond quality of the particleboards [20].

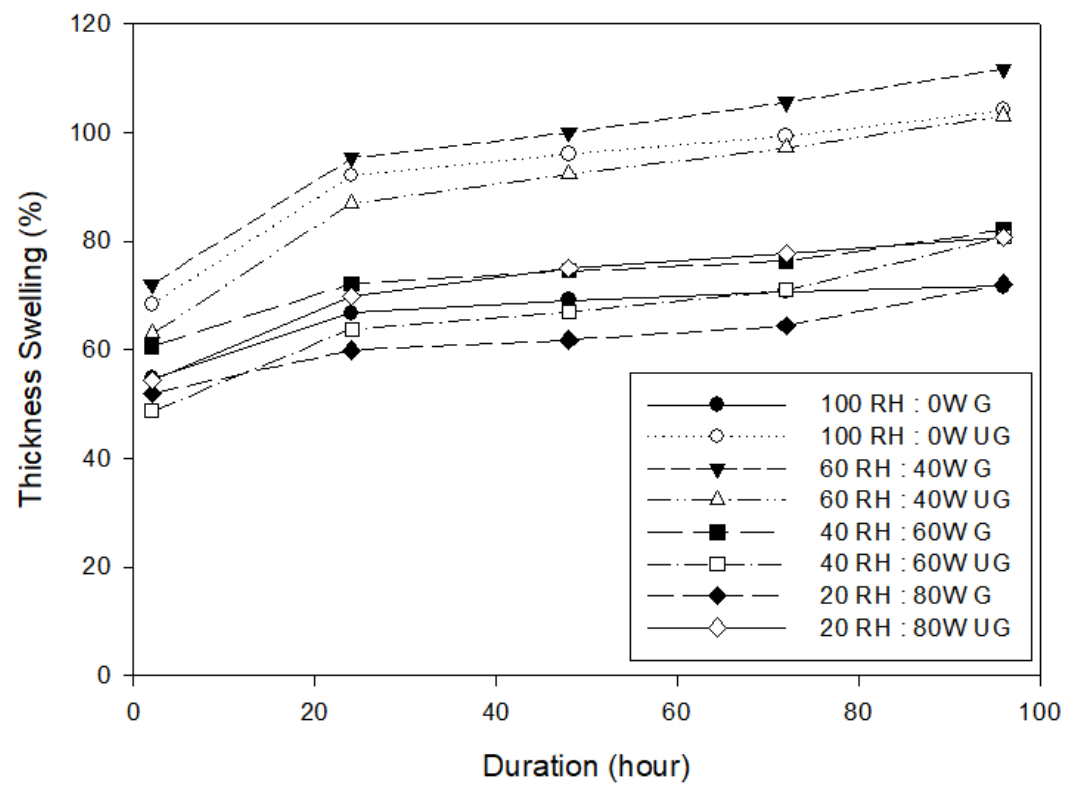

Fig. 1 - Thickness swelling of particleboard

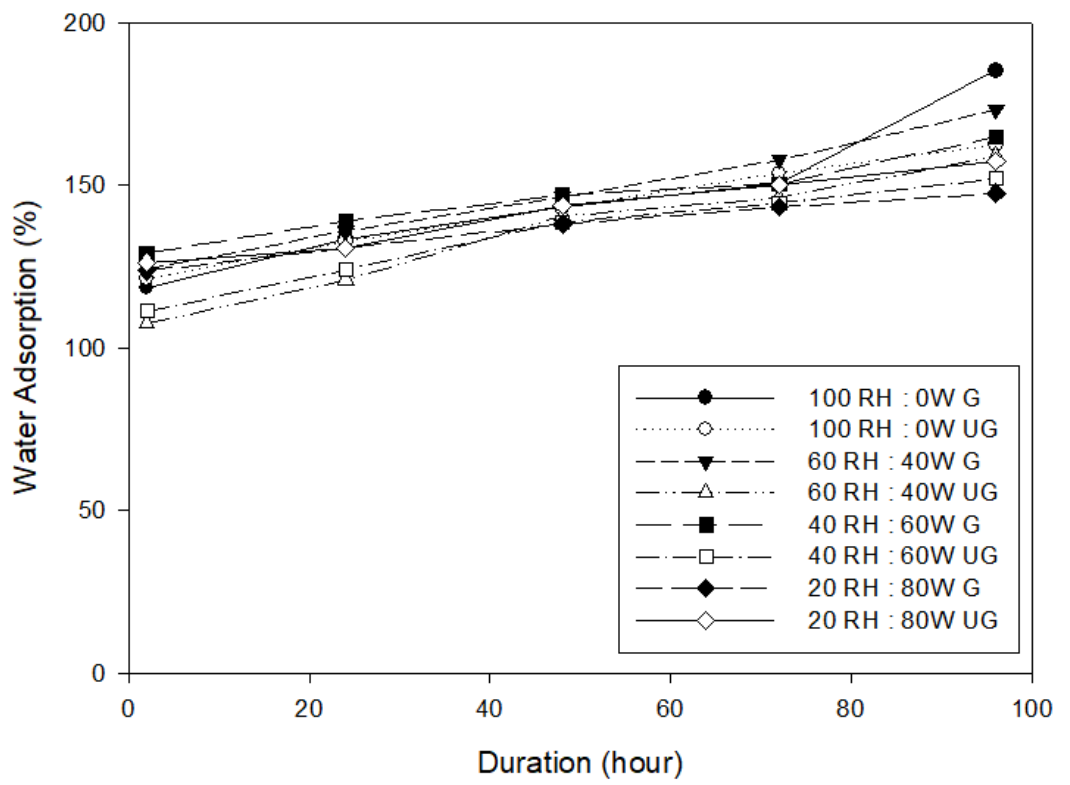

Fig. 2 - Water absorption of particleboard 


\subsection{Colour Analysis}

Surface colour is one of the major criteria in product quality evaluation [22]. Less variation of colour is preferred to have more uniform board panel during application. There were eight types of specimens with different composition of fibre loading and mixture. The colour of particleboards was observed between the relationship of the compositions and colour changes of the panel board. There were two types of particleboards which were the single layer particleboard A and $\mathrm{E}$ with $100 \%$ of rice husk and the three-layer particleboards B, C, D, F, G, and $\mathrm{H}$ with different ratios of rice husk and pinewood shaving. All three-layer particleboards have a bright brown colour as shown in Table 5, while the singlelayer particleboards were brown (darker) in colour. The colour of particles were no changes before and after sprayed resin and undergo the hot-pressing process, only some darker colour stain was due to the uneven resin sprayed. As can be seen from Table 5, in the single-layer particleboards namely A and E, apparently has no difference in colour between added and not added grinded rice husk.

Table 5 - Top view of particleboards with different ratio

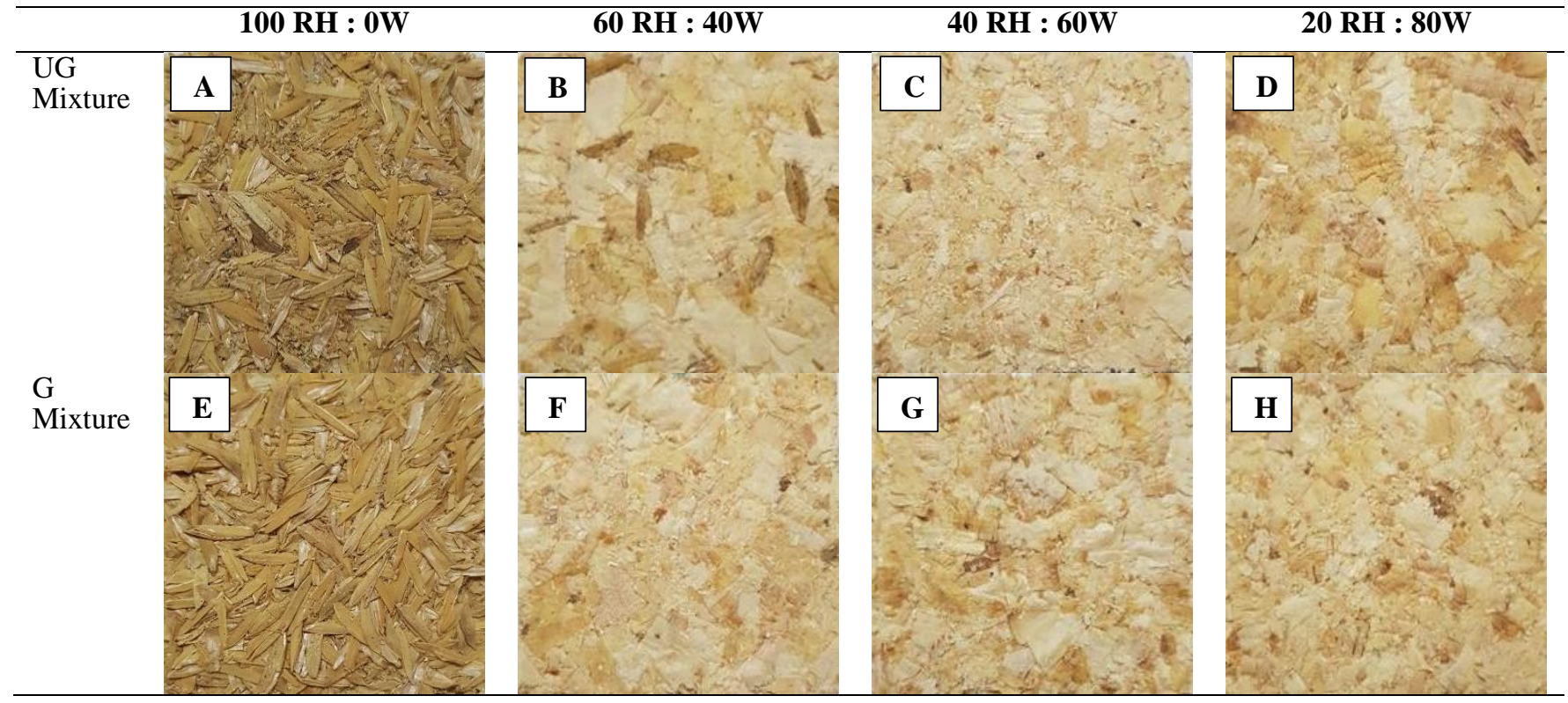

The particleboards in this experiment were only conducted until the hot pressing and trimming process. To commercialize the particleboards to market, the boards need to be complete by sanding and applying coatings or laminating [9]. The process of lamination or coating adds to the aesthetic value of the product and makes it look richer, elegant, and easily treated with fire retardants or with preservative chemicals. After all those processes, the particleboards can be used for various purposes by the end-users either interior or exterior.

\subsection{Void Content}

The void content of particleboards was observed from the edges part of the specimens. The four types of ratios in fibre loading were $100 \mathrm{RH}$ : $0 \mathrm{~W}, 60 \mathrm{RH}: 40 \mathrm{~W}, 40 \mathrm{RH}: 60 \mathrm{~W}$, and $20 \mathrm{RH}: 80 \mathrm{~W}$. While the ratio in mixture were added grinded rice husk into rice husk as shown in Table 6 . Therefore, all specimens were look different from the edge view due to the different ratios. The single-layer particleboards were produced by $100 \%$ of rice husk and grinded rice husk, whereas the three-layer particleboards were produced with pinewood shaving on both surface and rice husk in the middle layer.

After the hot-pressing process, the pinewood shaving (outer layer) had better compaction compared to the rice husk (inner layer). From observation, the voids in the rice husk were more obvious. However, the rice husk in specimens E, F, $\mathrm{G}$, and $\mathrm{H}$ were seen more compact compared to the rice husk in specimens $\mathrm{A}, \mathrm{B}, \mathrm{C}$, and $\mathrm{D}$. It may be due to the rice husk in specimens E, F, G, and $\mathrm{H}$ had added the grinded rice husk. The convex shape of rice husks created voids or gaps between the particles. When the particles have high void content which means there is lack of inseparable connection. While the finely grinded rice husk particles can fulfil the thicker rice husk particles, thus provides better compression and adhesion between particles. According to Halip et al. [15], the great quantity of voids not only leads to lower bonding and strength properties in the particleboards, but also reduces the values of modulus of elasticity (MOE) and modulus of rupture (MOR).

Besides, it can be seen from the figure that specimens D and $\mathrm{H}$ which have a ratio of $20 \mathrm{RH}: 80 \mathrm{~W}$ were more compact and fewer voids compared to specimens A and E with $100 \%$ rice husk. The same goes for the specimens of B, $\mathrm{C}, \mathrm{F}$, and $\mathrm{G}$ which have $40 \mathrm{RH}$ : $60 \mathrm{~W}$ and $60 \mathrm{RH}$ : $40 \mathrm{~W}$, the more proportion of pinewood shaving, the better compaction 
of particleboards. Hence, the large amount of pinewood shaving can cause the particleboards to have higher strength because pinewood shaving has fewer voids compared to rice husk after compression.

Ota and Okamoto [23] concluded that increasing the amount of rice husk particles in the particleboard was decreased the pore amounts concomitantly. Therefore, the study result indicated that the increment of pore amounts would lead to a decrease in mechanical properties due to it is more likely to fracture.

Table 6 - Side view of particleboards with different ratio



\section{Conclusions}

The particleboards made form rice husk and pine wood were successfully manufactured. According to the results, all of the particleboards have density values ranging from about 0.547 to $0.660 \mathrm{~g} / \mathrm{cm}^{3}$, and the moisture content of the particleboards manufactured ranged from about 8.072 to $8.929 \%$. Particleboards' density and moisture content both passed the standards of Japanese Industrial Standard A 5908:2003. Additionally, all three-layer particleboards have a uniform and bright colour surface compared to single-layer particleboards. In summary, the best sample for density and moisture content testing was the composition of $40 \mathrm{RH}$ : $60 \mathrm{~W}$ boards compared to other particleboards. While in terms of thickness swelling, water absorption, and void content, the optimum particleboard composition was the $20 \mathrm{RH}$ : $80 \mathrm{~W}$, as it had lower TS and WA values and less voids.

\section{Acknowledgement}

The research was supported by Universiti Tun Hussein Onn Malaysia (UTHM) through TIER1 (Vot H138).

\section{References}

[1] Singh, B. (2018). Rice Husk Ash, in Siddique \& Cachim. Waste and Supplementary Cementitious Materials in Concrete. Woodhead Publishing. pp. 417-460.

[2] Hazmi, B., Rashid, U., Taufiq-Yap, Y. H., Ibrahim, M. L., \& Nehdi, I. A. (2020). Supermagnetic Nano-bifunctional Catalyst from Rice Husk: Synthesis, Characterization and Application for Conversion of Used Cooking Oil to Biodiesel. Catalysts, 10(2).

[3] Abu Bakar, R., Yahya, R., \& Neon Gan, S. (2016). Production of High Purity Amorphous Silica from Rice Husk. Procedia Chemistry, 19, 189-195.

[4] Asha, A. (2017). Fabrication of Particle Boards from Rice Husk. International Journal of Modern Engineering Research, 7, 30-38.

[5] Umachandran, K., \& Sawicka, B. (2017). Study of Timber Market of Malaysia and Its Impact on the Economy and Employment. Journal of Advances in Agriculture, 7(3), 1109-1116.

[6] Shvidenko, A. (2008). Deforestation. Encyclopedia of Ecology, 4, 29-34.

[7] United Nations Environment Programme. (2017). Asia Waste Management. Group, 195-200.

[8] Abdullah, N. A., Sainorudin, M. H., Asim, N., Huda, N., Kadir, A., \& Yaakob, Z. (2020). Extraction of Microcrystalline Cellulose from Two Different Agriculture Waste via Chemical Treatment. IOP Conf. Ser.: Mater. Sci. Eng. 739012017.

[9] Popescu, C. M. (2017). Wood as Bio-based Building Material, in Jones \& Brischke. Performance of Bio-based Building Materials. Woodhead Publishing. pp. 21-96.

[10] United States Department of Agriculture. (2018). Grain: World Markets and Trade. 
[11] Baharuddin, M. N. M., Zain, N. M., Roslin, E. N., Harun, W. S. W., \& Zaeime. (2019). Physical Properties of Homogeneous Particleboard Based on Acacia Tree and Polyurethane Adhesive as a Resins. International Journal of Engineering and Advanced Technology, 8(6), 3382-3387.

[12] Atoyebi, O. D., Awolusi, T. F., \& Davies, I. E. E. (2018). Artificial Neural Network Evaluation of Cement-Bonded Particle Board Produced from Red Iron Wood (Lophira Alata) Sawdust and Palm Kernel Shell Residues. Case Studies in Construction Materials, 9, e00185.

[13] Chalapud, M. C., Herdt, M., Nicolao, E. S., Ruseckaite, R. A., Ciannamea, E. M., \& Stefani, P. M. (2020). Biobased Particleboards Based on Rice Husk and Soy Proteins: Effect of The Impregnation with Tung Oil on the Physical and Mechanical Behavior. Construction and Building Materials, 230, 116996.

[14] Nicolao, E. S., Leiva, P., Chalapud, M. C., Ruseckaite, R. A., Ciannamea, E. M., \& Stefani, P. M. (2020). Flexural and Tensile Properties of Biobased Rice Husk-Jute- Soybean Protein Particleboards. Journal of Building Engineering, 30, 101261.

[15] Halip, J. A., Hua, L. S., Md. Tahir, P., Al Edrus, S. S., Md Ishak, S. M., Selimin, M. A., \& Ab Hamid, A. A. R. (2019). Kenaf and Kenaf-rubberwood Hybrid Particleboards. International Journal of Recent Technology and Engineering, 8(2 Special Issue 4), 464-468.

[16] Johnson, A. C., \& Nordin, Y. B. D. E. D. (2009). Particleboards from rice husk: a brief introduction to renewable materials of construction. Cellulose, 28, 38.

[17] Astari, L., Prasetiyo, K. W., \& Suryanegara, L. (2018, June). Properties of particleboard made from wood waste with various size. In IOP Conference Series: Earth and Environmental Science (Vol. 166, No. 1, p. 012004). IOP Publishing.

[18] Harshavardhan, A., \& Muruganandam, L. (2017). Preparation and Characteristic Study of Particle Board from Solid Waste. IOP Conference Series: Materials Science and Engineering, 263(3).

[19] Ciannamea, E. M., Marin, D. C., Ruseckaite, R. A., \& Stefani, P. M. (2017). Particleboard based on rice husk: Effect of binder content and processing conditions. Journal of Renewable Materials, 5(5), 357-362.

[20] César, A. A. D. S., Bufalino, L., Mendes, L. M., Mesquita, R. G. D. A., Protásio, T. D. P., Mendes, R. F., \& Andrade, L. M. F. (2017). Transforming Rice Husk into a High-Added Value Product: Potential for Particleboard Production. Ciencia Florestal, 27(1), 303-313.

[21] Melo, R. R., Stangerlin, D. M., Santana, R. R. C., \& Pedrosa, T. D. (2014). Physical and Mechanical Properties of Particleboard Manufactured from Wood, Bamboo and Rice Husk. Materials Research, 17(3), 682-686.

[22] Unsal, O., Korkut, S., \& Atik, C. (2003). The effect of heat treatment on some properties and colour in eucalyptus (Eucalyptus camaldulensis Dehn.) wood. Maderas. Ciencia y tecnología, 5(2), 145-152.

[23] Ota, T., \& Okamoto, T. (2015). Mechanical Properties of Particleboard Made from Rice Husk. Journal of Materials Science and Engineering B, 5(8), 263-269. 